\title{
Pengaruh Resiko Kredit, Resiko Likuiditas, Efisiensi Manajemen terhadap Profitabilitas: Studi pada Perbankan yang Terdaftar di Bursa Efek Indonesia
}

\author{
Chairul Adhim \\ Sekolah Tinggi Ilmu Ekonomi Yapis Dompu \\ Email: chairuladhim@gmail.com
}

\begin{abstract}
This study aims to determine the effect of credit risk, liquidity risk, management efficiency to profitability in Banking listed on the Indonesia Stock Exchange in the period 2010-2014. This research is an explanatory research. The population of this study is a banking company listed on the Indonesia Stock Exchange using saturated sampling technique, obtained population of 26 banks. Analyzer using regression analysis. The result of analysis shows that Credit risk, and management efficiency have a negative and significant effect on profitability and liquidity risk have no effect on profitability, while the capital has a positive and significant effect on profitability.
\end{abstract}

Keywords: Profitability, Credit Risk, Liquidity Risk, Management Efficiency, Capital

\section{PENDAHULUAN}

Peran Industri perbankan merupakan tolok ukur kemajuan dalam mendukung perekonomian suatu negara tersebut. Apabila semakin baik peran industri perbankan maka semakin baik pula kondisi perekonomian pada negara yang bersangkutan (Bank Indonesia, 2015). Perbankan sebagai perantara keuangan dan sistem keuangan yang memiliki peran yang sangat strategis dalam menjaga stabilitas perekonomian baik pada saat gejolak ekonomi maupun pasca krisis terjadi.

Menurut laporan perekonomian pada tahun 2008, krisis keuangan tahun 2008 yang dipicu oleh krisis kredit perumahan produk sekuritas dan bangkrutnya beberapa perusahaan besar di Amerika Serikat ikut mempengaruhi perekonomian di Indonesia, salah satu sektor yang ikut mengalami dampaknya adalah sektorindustri perbankan. Sektor industri perbankan mengalami kesulitan likuiditas seiring dengan ketatnya likuiditas di pasar keuangan. Berdasarkan Grafik 1, dapat dilihat bahwa profitabilitas (Return on Asset) industri perbankan pada kuartal IV tahun 2008 sampai dengan kuartal I tahun 2009 menunjukan adanya penurunan tingkat keuntungan, hal ini disebabkan oleh tindakan perbankan yang cenderung lebih berhati-hati dalam menyalurkan kredit untuk menghindari risiko peningkatan kredit bermasalah. 


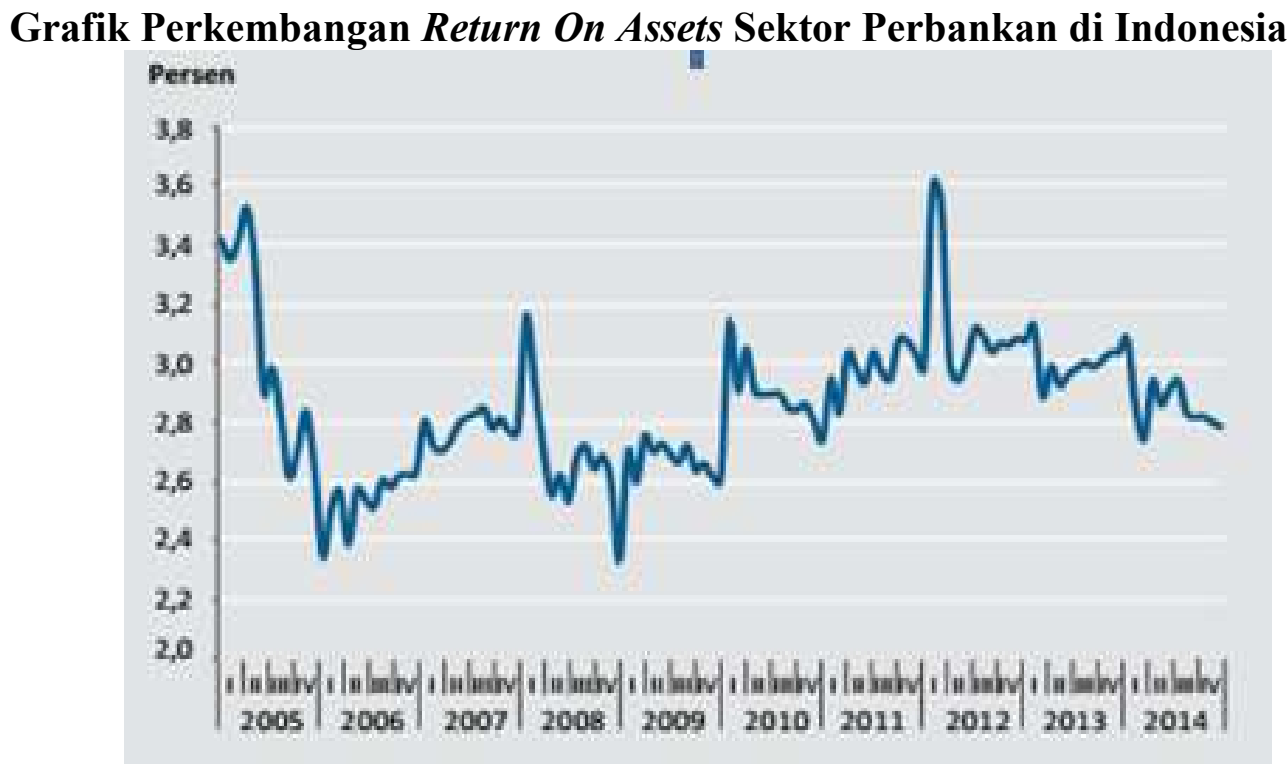

Sumber: Bank Indonesia: 2015

Berdasarkan laporan perekonomian Indonesia yang dikeluarkan oleh BI tahun 2008, perbankan mengeluarkan kebijakan secara umum ditandai dengan upaya untuk memperkuat ketahanan sistem perbankan dalam rangka mengurangi imbas krisis global pada perbankan domestik melalui penyesuaian ketentuan Fasilitas Pendanaan Jangka Pendek (FPJP). Di samping itu, Bank Indonesia terus melanjutkan berbagai kebijakan penguatan ketahanan perbankan, baik dalam kerangka Basel II maupun Arsitektur Perbankan Indonesia (API). Langkah tersebut termasuk pengaturan secara lebih mendalam, terkait dengan upaya peningkatan transparansi perbankan, penguatan efektivitas manajemen risiko likuiditas, dan produk-produk derivatif industri perbankan pada saat terjadi krisis keuangan.Hasil yang diperoleh setelah pelaksanaan kebijakan tersebut menunjukan peningkatan Profitabilitas (Return on Assets) Perbankan pada Grafik 1.1 perkembangan Return on Assets sektor perbankan di Indonesia, yang dapat dilihat terjadi peningkatan pada tiap kuartal pada tahun 2009. Hal ini membuktikan bahwa salah satu faktor yang menyebabkan mengapa perekonomian Indonesia memiliki daya tahan yang relatif lebih kuat, karena sistem keuangan, khususnya perbankan yang saat ini lebih kuat dalam menghadapi gejolak ekonomi global.

Pada tahun 2010 kinerja perekonomian semakin membaik, namun masih dihadapkan pada sejumlah tantangan utama yang terdiri dari derasnya aliran masuk modal asing, besarnya ekses likuiditas perbankan, inflasi yang meningkat, serta sejumlah permasalahan di sektor perbankan dan berbagai kendala di sektor riil. Sementara itu, untuk memperkuat stabilitas moneter dan sistem keuangan selain melalui kebijakan suku bunga, mulai pertengahan tahun 2010 Bank Indonesia juga menempuh kebijakan makro prudensial dalam rangka mengelola likuiditas domestik dan merespons derasnya arus modal asing. Bauran kebijakan tersebut juga didukung oleh berbagai 
kebijakan untuk menjaga stabilitas sistem keuangan serta berbagai kebijakan Pemerintah. Stabilitas Sistem Keuangan tetap terjaga di tengah ketidakpastian ekonomi global dan moderasi ekonomi domestik. Pencapaian tersebut tidak terlepas dari bauran kebijakan yang telah ditempuh oleh Bank Indonesia dan Pemerintah dalam rangka mendukung terjaganya Stabilitas Sistem Keuangan pada tahun 2010-2014. Meskipun dibayangi oleh dinamika ekonomi global yang kurang menguntungkan dan pertumbuhan ekonomi domestik yang melambat, kinerja industri perbankan tetap terjaga.

Berdasarkan penjelasan diatas, peran bank begitu vital menjaga kestabilan perekonomian, oleh sebab itu kinerja dan kesehatan bank sangat penting untuk terus dijaga dan ditingkatkan yang pada akhirnya akan membawa pengaruh kepada perekonomian yang lebih baik. Penelitian ini dikembangkan dari penelitian Yanuardi., et al (2014) dan pemilihan variabel dikembangkan berdasarkan Peraturan Bank Indonesia Nomor 3/1/PBI/2011 perihal Penilaian Tingkat Kesehatan Bank Umum. Ini dikarenakan untuk menguji pengaruh langsung dari variabel fundamental internal, adapun peneliti sebelumnya di antaranya Masdupi (2014), Yanuardi, et al (2014), Alshatti (2015), Buchory (2015), Haryanto (2015), Shingjergji dan Hyseni (2015), dan Suardirta dan Asri (2015)). Adapun yang menjadi variabel terikat profitabilitas yang diproksi menggunakan Return on Asset (ROA). Untuk variabel bebas risiko kredit sebagai pengukuran digunakan Non performing loan (NPL) dan risiko likuiditas menggunakan proksi Loan to Deposit Ratio (LDR), variabel bebas lainya adalah variabel efisiensi manajemen menggunakan pengukuran rasio biaya operasional dan biaya pendapatan (BOPO). Serta variabel permodalan menggunakan pengukuran Capital Adequency Ratio (CAR). Jadi Masih banyaknya perbedaan hasil penelitian terdahulu sehingga menjadi celah melakukan kajian ulang pengaruh risiko kredit, risiko likuiditas, efisiensi manajemen, permodalan terhadap profitabilitas.

Profitabilitas adalah kemampuan perusahaan memperoleh laba dalam hubungannya dengan penjualan, total aktiva maupun modal sendiri (Sartono, 2010:122). Sedangkan menurut Harmono (2009:109) Profitabilitas merupakan suatu kemampuan yang menggambarkan kinerja fundamental perusahaan yang ditinjau dari tingkat efisiensi dan efektivitas operasi perusahaan dalam memperoleh laba. Adapun dalam penelitian ini profitabilitas menggunakan indikator rasio ROA sebagai variabel terikat. Nilai ROA didapatkan dari perbandingan laba bersih dengan total aset perusahaan. ROA dikemukakan oleh Sartono (2010:123) adalah menunjukan kemampuan perusahaan dalam menghasilkan laba dari aktiva yang digunakan. Sedangkan Menurut Sudana (2011:22), ROA menunjukan kemampuan perusahaan dengan mengunakan seluruh aktiva yang dimiliki untuk menghasilkan laba setelah pajak.

Risiko kredit adalah resiko yang timbul karena debitur tidak dapat mengembalikan dana yang dipinjam dan bunga yang harus dibayar kepada bank (Latumaerissa, 2014:8). Sedangkan Rose dan Hudgins (2008) menyatakan bahwa bank sebagai lembaga intermediary memberikan kredit dan surat berharga dengan harapan pengembalian dan mendapatkan pendapatan bunga atas aktivitas tersebut, namun ketika terjadi default atas kredit dan surat berharga akan mengurangi modal bank dimana pemilik modal bank menyediakan $10 \%$ atau kurang untuk menutupi kerugian yang 
CENDEKIA, Vol. 13 No. 2 Oktober 2019

p ISSN: 1978 2098; e ISSN: 2407 8557

Https://soloclcs.org; Email: cendekiaoslo@gmail.com

Center of Language and Cultural Studies, Surakarta, Indonesia

Adhim, Chairul. (2019). Pengaruh Resiko Kredit, Resiko Likuiditas, Efisiensi Manajemen terhadap

Profitabilitas: Studi pada Perbankan yang Terdaftar di Bursa Edfek Indonesia. Cendekia (2019), 13(2): 141 152. DOI: 10.30957/cendekia.v13i2.604.

berasal dari default kredit bermasalah ataupun surat berharga tersebut. Perhitungan yang digunakan untuk mengukur risiko kredit adalah rasio NPL. Rasio NPL didapatkan dari perbandingan kredit bermasalah dengan total kredit. NPL menjelaskan kondisi kredit suatu bank, dengan melihat kredit bermasalah pada suatu bank. Akan tetapi NPL akan sangat mempengaruhi profitabiltas suatu bank, karena semakin kecil NPL maka semakin bagus kinerja bank, apabila sebaliknya jika NPL tinggi dapat mengindikasikan kredit bermasalah banyak terjadi yang mengakibatkan menurunnya profitabiltas.

Risiko likuiditas merupakan pengukuran risiko yang dihadapi bank apabila gagal untuk memenuhi kewajibannya kepada para deposannya dengan aset likuid yang dimilikinya (Kasmir, 2012b:320). Rose dan Hudgins (2008) menyatakan bahwa bank menghadapi ancaman risiko likuiditas, yaitu tidak adanya dana yang digunakan untuk menutup penarikan simpanan nasabah dan permintaan kredit yang diajukan oleh nasabah. Adapun perhitungan yang digunakan untuk mengukur risiko kredit adalah LDR. LDR membandingkan kredit dengan dana pihak ketiga. LDR banyak digunakan untuk mengukur tingkat likuiditas bank, semakin tinggi tingkat rasio ini, maka tingkat likuiditasnya akan semakin kecil, karena jumlah dana yang diperlukan untuk membiayai kreditnya semakin banyak (Muljono, 1995 dalam Fitrianto, et al 2006).

Efisiensi manajemen menurut Rose dan Hudgins (2008) adalah salah satu untuk memaksimalkan keuntungan dan nilai investasi pemegang saham, lembaga perbankan perlu untuk lebih efisien dalam pelaksanaan operasional, hal ini berarti mengurangi biaya operasional dan meningkatkan produktivitas karyawan melalui penggunaan peralatan otomatis dan peningkatan pelatihan karyawan. Disertai dengan adanya deregulasi pemerintah misalnya, untuk membayar biaya bunga yang lebih tinggi untuk mendapatkan dana hal tersebut akan mendorong manajemen untuk mengurangi biaya bukan bunga, terutama gaji karyawan dan biaya overhead. Pencapaian efisiensi manajemen bank biasanya menggunakan pengukuran rasio BOPO (Peraturan Bank Indonesia Nomor 14/26/PBI/2012Pasal 21 No 2, Sastrosuwito dan Suzuki (2011) serta Rose dan Hudgins (2008)). Menurut Dendawijaya (2009:119) BOPO adalah perbandingan antara biaya operasional dengan pendapatan operasional. Rasio ini digunakan untuk mengukur tingkat efisiensi dan kemampuan bank dalam melakukan kegiatan operasinya. BOPO yang dihasilkan semakin rendah maka kinerja manajemen dari bank tersebut berarti semakin baik. Hal tersebut menunjukkan bahwa bank lebih efisien dalam menggunakan sumber daya yang ada untuk kegiatan operasionalnya.

Permodalan bagi bank sebagaimana perusahaan pada umumunya, selain berfungsi sebagai sumber utama pembiayaan terhadap kegiatan operasional juga sebagai penyangga terhadap semua kemungkinan terjadinya kerugian. Selain itu, modal juga berfungsi untuk menjaga kepercayaan masyarakat terhadap kemampuan bank dalam menjalankan fungsinya sebagai lembaga intermediasi (Latumerisa, 2014). Salah satu penilaian permodalan bank adalah dengan metode rasio kecukupan modal (CAR) (Kasmir 2012b:301). Menurut Kasmir (2010:232) rasio kecukupan modal dapat merupakan rasio yang digunakan untuk mengukur permodalan dan cadangan penghapusan dalam menanggung perkreditan, terutama resiko yang terjadi karena bunga gagal ditagih.Jika nilai CAR tinggi, maka bank tersebut mampu membiayai kerugian 
dari setiap kredit/aktiva produktif yang berisiko akibat dari kegiatan operasional dan memberikan kontribusi besar terhadap profitabilitas.

\section{Kerangka Konseptual Penelitian}

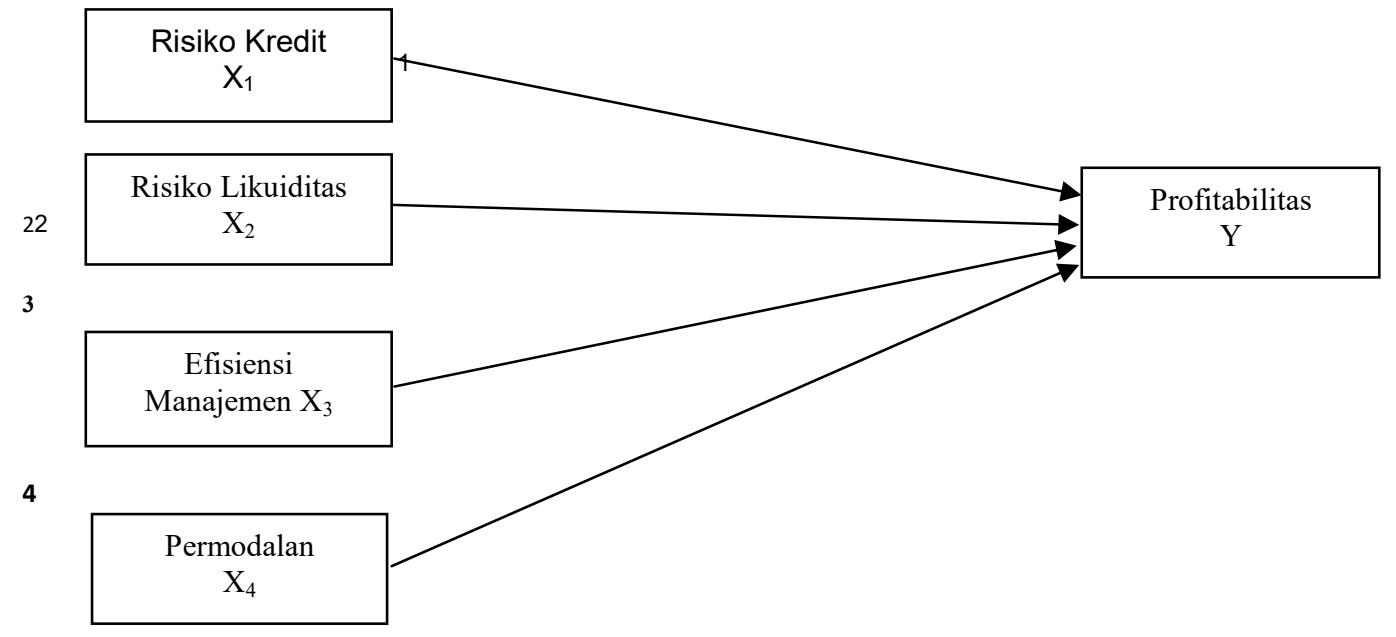

H1 : Risiko Kredit berpengaruh signifikan terhadap Profitabilitas.

H2 : Risiko likuiditas berpengaruh signifikan terhadap profitabilitas.

H3 : Efisiensi manajemen berpengaruh signifikan terhadap profitabilitas.

H4 : Permodalan berpengaruh signifikan terhadap Profitabilitas.

\section{METODE}

Jenis penelitian iniadalah explanatory research. Penelitian explanatory research merupakan penelitian dengan karakteristik berupa hubungan sebab-akibat antara dua variabel atau lebih yang menguji hubungan antar variabel melalui pengujian hipotesis (Sugiyono 2012:21).

Populasi dalam penelitian adalah perusahaan-perusahaan perbankan yang listing di Bursa Efek Indonesia selama periode tahun 2010-2014. Teknik sampling menggunakan sampling jenuh, yang merupakan teknik penetuan sampel bila semua anggota populasi digunakan sebagai sampel (Sugiyono, 2008:85). Adapun kriteria pengambilan populasi dalam penelitian ini adalah sebagai berikut:

Tabel Kriteria Populasi

\begin{tabular}{|l|c|}
\hline Kriteria Populasi & Jumlah \\
\hline $\begin{array}{l}\text { Perusahaan perbankan yang terdaftar secara terus menerus selama } \\
\text { tahun 2010-2014 }\end{array}$ & 29 \\
\hline Perusahaan perbankan yang rugi selama tahun 2010-2014 & 3 \\
\hline Jumlah populasi yang diteliti & 26 \\
\hline
\end{tabular}

Sumber : Data Diolah 2017

Jenis data yang digunakan dalam penelitian ini adalah data sekunder. Data sekunder yang dikumpulkan adalah data-data sekunder berupa laporan keuangan tahunan yang dipublikasi bank selama periode tahun 2010-2014. Teknik Pengumpulan Data yang digunakan dalam penelitian ini yaitu melalui Dokumentasi. Tehnik 
dokumentasi merupakan teknik pengumpulan data dengan melihat dan mencatat dari publikasi perusahaan, yang berkaitan dengan data tentang laporan keuangan perusahaan yang terdiri dari neraca, laporan laba rugi, laporan arus kas, laporan perubahan modal, dan catatan atas laporan keuangan. Metode analisis data yang digunakan pada penelitian ini menggunakan bantuan SPSS 23.0 for windows. Alat analisis yang digunakan adalah analisis regresi dan uji hipotesis.

\section{HASIL DAN PEMBAHASAN}

Pengujian Hipotesis Pengaruh Langsung
\begin{tabular}{|l|c|c|r|r|r|}
\hline Independent & Dependent & $\boldsymbol{\beta}$ & Std. Error & t-hitung & p-value \\
\hline NPL & & $-0,268$ & 0,036 & $-4,448$ & 0,000 \\
LDR & \multirow{3}{*}{ ROA } & $-0,106$ & 0,015 & $-1,842$ & 0,068 \\
BOPO & & $-0,547$ & 0,019 & $-9,132$ & 0,000 \\
CAR & & 0,213 & 0,051 & 3,505 & 0,001 \\
\hline
\end{tabular}

Sumber: Lampiran

\section{Pengaruh Risiko Kredit terhadap Profitabilitas}

Hasil penelitian menunjukan bahwa risiko kredit berpengaruh negatif dan signifikan terhadap profitabilitas. Hal ini menunjukan bahwa bank mampu menyalurkan dan mengelola kredit dengan baik tercermin dari rendahnya nilai NPL, sehingga berdampak terhadap meningkatnya profitabilitas bank. Apalagi pendapatan perbankan yang ada di Indonesia masih di dominasi oleh pendapatan bunga. Sehingga bank mendapatkan pendapatan bunga dari penyaluran kreditnya secara optimal.

Hasil penelitian ini konsisten dengan penelitian Alper dan Anbar (2011) dan Masdupi (2014) yang menyatakan bahwa hubungan negatif dan signifikan antara NPL dan ROA. Hasil penelitian ini tidak konsisten dengan penelitian yang diperoleh Buchory (2015), yang menunjukan bahwa NPL positif tapi tidak signifikan terhadap ROA sedangkan Alshatti (2015), menunjukan bahwa NPL positif berpengaruh terhadap ROA.

\section{Pengaruh Risiko Likuiditas terhadap Profitabilitas}

Hasil penelitian menunjukan bahwa risiko likuiditas tidak berpengaruh terhadap profitabilitas. Hal ini mengindikasikan bahwa tingginya risiko likuditas tidak menyebabkan tingginya pencapaian laba atau profitabilitas bank. Hal ini dikarenakan bank cukup berhati-hati dalam menyalurkan dana dalam rangka menjaga likuiditasnya. Sehingga besarnya rasio ini juga tergantung dengan kebijakan dan strategi yang digunakan manajemen bank untuk memanfaatkan aset likuid yang dimiliki guna mendapatkan keuntungan. Oleh karena itu risiko likuiditas dalam penelitian tidak mempunyai pengaruh atau dampak terhadap profitabilitas bank di Indonesia.

Hasil penelitian ini konsisten dengan penelitian Buchory (2015), yang menegaskan bahwa likuiditas (LDR) memiliki dampak negatif tidak siginifikan 
terhadap profitabilitas (ROA). Hasil penelitian ini tidak konsisten dengan penelitian Alper dan Albar (2011), Yanuardi, et al, (2014) dan Masdupi (2014) yang menunjukan bahwa risiko likuiditas berpengaruh tidak penting terhadap profitabilitas.

\section{Pengaruh Efisiensi Manajemen terhadap Profitabilitas}

Hasil penelitian menunjukan bahwa efisiensi manajemen berpengaruh negatif dan signifikan terhadap profitabilitas. Hal ini sesuai dengan teori bahwa rasio perbandingan biaya operasional terhadap pendapatan operasional manajemen memiliki hubungan negatif dengan profitabilitas. Ini mengindikasikan bahwa semakin menurun efisiensi manajemen (BOPO), artinya bank semakin efisien bank dalam penggunaan sumber daya dalam kegiatan operasional bank. Sehingga pada akhirnya berdampak terhadap meningkatnya profitabilitas yang akan diperoleh. Karena semakin efisien manajemen bank dalam mengendalikan biaya yang akan berdampak terhadap berkurangnya beban biaya yang ditanggung oleh bank sehingga mampu meningkatkan laba atau profitabilitas. Hasil penelitian ini konsisten dengan penelitian Masdupi (2013), Sastrosuwito dan Suzuki (2012), dan Buchory (2015) menyatakan bahwa secara berpengaruh signifikan dan memiliki hubungan negatif terhadap profitabilitas.

\section{Pengaruh Permodalan terhadap Profitabilitas}

Hasil penelitian menunjukan terdapat pengaruh positif dan signifikan permodalan terhadap profitabilitas. Hal ini menunjukan bahwa semakin tinggi nilai CAR, maka semakin tinggi kesempatan bank dalam menghasilkan laba. Karena bank dengan tingkat kecukupan modal yang tinggi, bank akan leluasa dalam menggunakan dananya untuk menopang kegiatan operasional, pengembangan fasilitas dan kemampuan menyerap risiko lebih besar dan pada akhirnya akan berdampak terhadap meningkatnya profitablitas yang diperoleh bank.

Hasil penelitian ini konsisten dengan hasil kajian dari Olalekan dan Adeyinka (2013), Yanuardi et al (2014), Suardita dan Asri (2015) yang menyatakan bahwa modal memiliki pengaruh signifikan dan berkorelasi positif terhadap profitabilitas. Hasil penelitian ini tidak konsisten dengan penelitian Alper dan Anbar (2011) menunjukan bahwa permodalan tidak berpengaruh signifikan terhadap profitabilitas bank.

\section{SIMPULAN}

Pengaruh risiko kredit negatif dan signifikan terhadap profitabilitas, artinya bahwa risiko kredit yang semakin menurun dapat meningkatkan profitabilitas. Hal ini menunjukan bahwa bank mampu menyalurkan dan mengelola kredit dengan baik yang mana hal itu tercermin dari rendahnya nilai risiko kredit (NPL) yang berdampak terhadap meningkatnya profitabilitas bank.

Pengaruh risiko likuditas negatif dan tidak signifikan terhadap profitabilitas, menunjukan tingginya risiko likuditas tidak menyebabkan tingginya pencapaian laba atau profitabilitas bank. Hal ini dikarenakan bank cukup berhati-hati dalam menyalurkan dana dalam rangka menjaga likuiditasnya.Pengaruh efisiensi manajemen negatif dan signifikan terhadap profitabilitas, mengindikasikan bahwa efisiensi manajemen semakin menurun artinya semakin baik kinerja bank dalam hal efisiensi dan 
dalam meminimalisir biaya operasional bank. Sehingga, pada akhirnya berdampak pada meningkatnya profitabilitas.Pengaruh permodalanpositif dan signifikan terhadap profitabilitas, menunjukan bahwa permodalan yang semakin tinggi menunjukan bahwa semakin tinggi tingkat permodalan (CAR) maka semakin tinggi kesempatan bank dalam menghasilkan laba atau profitabilitas.

\section{Saran}

Penelitian selanjutnya dapat memperluas objek penelitian, tidak hanya terbatas pada industri perbankan, akan tetapi lebih jauh lagi dapat menggunakan objek industri lain dan memperpanjang periode pengamatan penelitian agar memperoleh hasil yang lebih baik.Serta hendaknya dapat menggunakan atau memperluas proksi dalam penggunaan variabel internal lainnya dan penambahan faktor dari variabel eksternal atau makroekonomi.

Bagi manajemen bank hendaknya memperhatikan strategi dalam pengelolaan likuditas (LDR). Sehingga modal menjadi dana produktif yang dapat menghasilkan laba dan dapat meningkatkan kinerja bank.Perbankan harus senantiasa mengoptimalkan penggunaan modal, selain digunakan sebagai penyangga terhadap risiko, modal juga dapat digunakan dalam rangka mendukung kegiatan operasional bank, yaitu; dapat digunakan untuk mendukung pertumbuhan perusahaan dan untuk pengembangan layanan serta fasilitas baru.

\section{DAFTAR PUSTAKA}

Abdullah, Faisal. 2003. Manajemen Perbankan (Teknik Analisis Kinerja Keuangan Bank). Malang: Universitas Muhammadiyah Malang (UMM) Press.

Alper, Deger., dan Anbar, Adem. 2011. Bank Specific and Macroeconomic Determinants of Commercial Bank Profitability: Empirical Evidence from Turkey. Business and Economics Research Journal, 2(2), pp: 139-152.

Alshatti, Ali Sulieman. 2015. The effect of credit risk management on financial performance of the Jordanian commercial banks. Investment Management and Financial Innovations, Volume 12, Issue 1, 2015.

Amer, Hager H.M., Moustofa, Wael., and Eldomiaty, Tarek. 2014. Determinant Of Efficiency for Lowly and Highly Competitive Banks in Egypt. Cambridge Business \& Economics Conference. ISBN : 9780974211428

Aremu, M.A., Ekpo, I.C., dan Mustapha, A.M. 2013. Determinants Of Banks' Profitability In A Developing Economy: Evidence From Nigerian Banking Industry, Interdisciplinary Journal Of Contemporary Research In Business. Vol 4, No 9, pp. 155-181.

Bank Indonesia. 2009. Menjaga Stabilitas Perekonomian dalam Krisis Keuangan Global. Laporan Perekonomian tahun 2008. Jakarta : Bank Indonesia. Diunduh:http://www.bi.go.id/id/publikasi/laporantahunan/perekonomian/Pages/lpi 2008.aspx

Bank Indonesia. 2015. Memperkokoh Stabilitas, Mendorong Reformasi Struktural untuk Pertumbuhan Ekonomi yang Berkelanjutan. Laporan Perekonomian tahun 2014. Jakarta : Bank Indonesia. Diunduh 
http://www.bi.go.id/id/publikasi/laporantahunan/perekonomian/pages/LPI_2014.a $\operatorname{spx}$

Boklet perbankan. 2016. Edisi Ke 3. ISNN 1858-423. http//:www.ojk.go.id

Buchory, Herry Achmad. 2015. Banking Intermediation, Operational Efficiency And Credit Risk In The Banking Profitability. Proceeding - Kuala Lumpur International Business, Economics and Law Conference 7, Vol. 2. August 15 16, 2015. Hotel Putra, Kuala Lumpur, Malaysia. ISBN 978-967-11350-4-5.

Dendawijaya, Lukman. 2009. Manajemen Perbankan. Jakarta: Ghalia Indoensia

Darmawi, Herman. 2012. Manajemen Perbankan. Cetakan Kedua. Bumi Aksara: Jakarta

Gezu, Gadise. 2014. Determinants of Non performing Loans: Empirical Study in Case of Commercial Banks in Ethiopia. A thesis submitted to school of postgraduate in partial fulfillment of the requirements for the degree of masters of science (msc) in accounting and finance. Jimma university business and economics college department of accounting and finance. Online.

Ganić, Mehmed. 2014. Bank Specific Determinants of Credit Risk - An Empirical Study on the Banking Sector of Bosnia and Herzegovina. International Journal of Economic Practices and Theories, Vol. 4, No. 4, 2014 (July), e-ISSN 2247-7225. www.ijept.org

Ghozali, Imam. 2006. Structural Equation Modeling Metode Alternatif dengan Partial Least Square. Semarang: Badan Penerbit Universitas Diponegoro.

Ghozali, Imam. 2012. Aplikasi Analisis Multivariate dengan Program IBM SPSS 20 (Edisi 6). Semarang : Badan Penerbit Universitas Diponegoro.

Harahap, S.S. 2010. Analisis Kritis Atas Laporan Keuangan, Edisi Pertama. PT RajaGrafindo Persada. Jakarta.

Hasan Ayaydin dan Aykut Karakaya. 2014. Turkey The Effect of Bank Capital on Profitability and Risk in Turkish Banking. International Journal of Business and Social Science Vol. 5 No. 1; January 2014.

Julita. 2011. Pengaruh Non Performing Loan (Npl) Dan Capital Adequacy Ratio (Car) Terhadap Profitabilitas (Roa) Pada Perusahaan Perbankan Yang Terdaftar Di Bei. Vol 1, No 1 2011. http://jurnal.umsu.ac.id/

Kasmir. 2012a. Analisis Laporan Keuangan, Edisi Pertama, Cetakan Kelima. Raja Grafindo Persada. Jakarta. . 2012b. Manajemen Perbankan, Edisi Revisi, Cetakan Sebelas. PT RajaGrafindo Persada. Jakarta.

Latumaerissa, Julius R. 2014. Manajemen Bank. Edisi Asli. Mitra Wacana Media. Jakarta.

Maheswari, Kadek Indah dan Sudirman, I Made Surya Negara. 2014. Pengaruh NPL terhadap ROA dengan mediasi CAR dan BOPO pada Perbankan Indonesia. Fakultas Ekonomi dan Bisnis Universitas Udayana (Unud), Bali, Indonesia. EJurnal Manajemen Unud Hal 1119-1138.

Masdupi, Erni. 2014. Pengaruh Efisiensi Operasional Terhadap Profitabilitas Sektor Perbankan. Fakultas Ekonomi Universitas Negeri Padang. Jurnal Kajian Manajemen Bisnis Volume 3, Nomor 1, Maret 2014. 
Olalekan, Asikhia dan Adeyinka, Sokefun. 2013. Capital Adequacy And Banks' Profitability: An Empirical Evidence From Nigeria. American International Journal of Contemporary Research Vol. 3 No. 10; October 2013

Prastowo, D. 2011. Analisis Laporan Keuangan: Konsep dan Aplikasi, Edisi Ketiga, Cetakan Pertama. Unit Penerbit dan Percetakan Sekolah Tinggi Ilmu Manajemen YKPN. Yogyakarta.

Rose, Peter S dan Hudgins, Sylvia C. 2008. Bank management \& Financial Service, Seventh Edition Mc Graw-Hill/Irwin. America Newyork.

Sanusi, Anwar. 2011. Metodologi Penelitian Bisnis. Jakarta : Salemba Empat

Sartono, Agus. (2010). Manajemen Keuangan Teori dan Aplikasi. (Edisi IV). Yogyakarta : BPFE.

Sastrosuwito, S. dan Suzuki, Y. 2012. The Determinants Post-Crisis Indonesian Banking System Profitability. Economics and Finance Review Vol. 1(11) pp. 48 57, January, 2012. ISSN: 2047 - 0401. Available online at http://www.businessjournalz.org/efr

Septiani, Rita dan Lestari, Putu Vivi. 2016. Pengaruh NPL dan LDR terhadap Profitabilitas dengan CAR sebagai variabel mediasi pada PT BPR pasarraya kuta. Fakultas Ekonomi dan Bisnis Universitas Udayana (Unud), Bali, Indonesia. EJurnal Manajemen Unud, Vol. 5, No.1, 2016: 293 - 324. ISSN: 2302-8912 293.

Shingjergji, Ali dan Hyseni, Marsida. 2015. The Determinants Of The Capital Adequacy Ratio In The Albanian Banking System During 2007 - 2014. Lecturers at Finance and Accounting Department, Faculty of Economy University of Elbasan "Aleksandër Xhuvani", Elbasan. Albania International Journal of Economics, Commerce and Management United Kingdom Vol. III, Issue 1, Jan 2015. ISSN 2348 0386. http://ijecm.co.uk/

Suadirta, I Wayan dan Asri Dwija Putri, I.G.A. 2015. Pengaruh Kecukupan Modal dan Penyaluran Kredit Pada Profitabilitas Dengan Pemoderasi Risiko Kredit. Fakultas Ekonomi dan Bisnis Universitas Udayana, Bali. E-Jurnal Akuntasi Universitas Udayana 11.2 (2015): 426-440. ISSN: 2302-8556.

Sudana, I Made (2011). Manajemen Keuangan Perusahaan, Teori dan Prktik. Jakarta: Erlangga.

Sudiyatno, Bambang dan Fatmawati, Asih (2013). Pengaruh Risiko Kredit Dan Efisiensioperasional Terhadap Kinerja Bank (Studi Empirik pada Bank yang Terdaftar di Bursa Efek Indonesia). Jurnal Organisasi dan Manajemen, Volume 9, Nomor 1, Maret 2013, 73-86.

Sugiyono. 2012. Metode Penelitian Bisnis (Pendekatan Kuantitatif, Kualitatif dan R \& D) Edisi 16. Bandung : Alfabeta.

Suryanto. 2015. Non Performing Loans on Regional Development Bank in Indonesia and Factors that Influence. Department of Business Administration, Padjadjaran University. Mediterranean Journal of Social Sciences. MCSER Publishing, RomeItaly. Vol 6 No 4 July 2015. ISSN 2039-2117 (online).

Suteja, Jaja dan Ginting, Gerinata. 2014. Determinan profitabilitas Bank: Suatu studi pada Bank yang Terdaftar di BEI. Fakultas Ekonomi Universitas Pasundan. 
Trinomika Volume 13, No.1, Juni 2014, Hal 62-77. ISSN 1411-514X (Print)/ ISSN2355-7737 (online).

Waqas, Tariq. 2014.Determinants of Commercial Banks Profitability. International Journal of Accounting and Financial Reporting, Vol. 4, No. 2.

Yanuardi, Alindra., Hadiwidjojo, Djumilah dan Sumiati (2014). Faktor Determinan Atas Profitabilitas Perbankan Yang Terdaftar Di Bursa Efek Indonesia. Jurnal Akuntansi Multiparadigma, Volume 5, Nomor 2, Agustus 2014.

Yuanjua dan Shishun, Xiao. 2012. Effectiveness of China's Commercial Banks' Capital Adequacy Ratio Regulation A Case Study of The Listed Bank. Master, College of Economics and Management, Sichuan Agricultural University, Chengdu , Sichuan, China (611130). Interdisciplinary Journal Of Contemporary Research In Business Copy Right 58 MAY 2012 VOL 4, NO 1.

Yuliani, YL. 2013. Aktivitas Operasional Bank dan Implikasinya terhadap Kinerja Keuangan dengan Faktor Risiko sebagai Pemediasi (Studi pada Sektor Perbankan Go Public di Bursa Efek Indonesia). In: Seminar Nasional Asosiasi Ilmuwan Manajemen Indonesia (AIMI) 2013, 21-22 Juni 2013, Kendari-Sulawesi Tenggara. http://eprints.unsri.ac.id/4716/. 
CENDEKIA, Vol. 13 No. 2 Oktober 2019

p ISSN: 1978 2098; e ISSN: 2407 8557

Https://soloclcs.org; Email: cendekiaoslo@gmail.com

Center of Language and Cultural Studies, Surakarta, Indonesia

Adhim, Chairul. (2019). Pengaruh Resiko Kredit, Resiko Likuiditas, Efisiensi Manajemen terhadap

Profitabilitas: Studi pada Perbankan yang Terdaftar di Bursa Edfek Indonesia.

Cendekia (2019), 13(2): 141 152. DOI: 10.30957/cendekia.v13i2.604. 